\title{
Analysis and Mapping of Stakeholders in Traditional Use Zone within Marine Protected Area
}

\author{
Roni Bawole \\ Department of Marine Science, Faculty of Animal Husbandry, Fisheries and Marine Science, Papua State University, \\ Gunung Salju Street, Amban, Manokwari 98314, Indonesia
}

Received April 19, 2012/Accepted May 23, 2012

\begin{abstract}
This research is greatly needed in order to accommodate the interest and influence of stakeholders and to find solution to conflict of interests among the stakeholders. As a case study, it was conducted in traditional utilization zone of Cendrawasih Bay National Park (CBNP) at Teluk Wondama Regency from August 2010 to June 2011 using qualitative method. The aim of the research was to formulate pro-and-contra conditions that might have a potential to create conflicts and to find out suitable strategies to resolve the conflicts to improve governance and management. The result shows that most stakeholders are mapped as key players of conflicts interest. The analysis also found that stakeholders were distributed as a subject, key player, and context setter, and no stakeholder was classified as a crowd category. This result implied that most stakeholders have an interests and influences to create good governance and to keep a sustainable development in the traditional use zone. Based on this finding, it can be stated that the existing conflict patterns were categorized as open and latent conflicts. These conflicts can be resolved by creating collaboration among Management Body local community, NGOs, and local government through strengthening the institutional capacity for the management of traditional use zone.
\end{abstract}

Keywords: stakeholders, conflict and conflict resolution, traditional use zone, marine conservation

*Correspondence author, email: ronibawole@yahoo.com, telp. +62-986-211675, fax. +62-986-211455

\section{Introduction}

Many publications stated that low rate of project achievement is caused by the failure in decision making, or even only halves of the decision could be implemented with unsatisfied results (Evans 2009). In a wider scale, the decision makers (managers) often failed to give attention to and capture the interest of stakeholders. Qualitative and quantitative studies showed that interest and influence of stakeholders play important roles in the process of problem solving, planning, and decision making (Bryson et al. 2011).

Currently, stakeholder analysis is becoming very important in understanding the processes of activities being carried out, because increased relationship between concerned institutions can not be avoided. Stakeholder analysis becomes a good instrument in identifying problems and finding the solution through cooperation and role allocation of stakeholders. Additionally, a stakeholder analysis becomes very important in creating an effective management, good governance, and understanding relationship among area users.

A comprehensive and effective management of Cenderawasih Bay National Park (CBNP) is not sufficient or still weak (Sembiring et al. 2010). To anticipate increasing local pressures, the governance of traditional use zone of marine conservation area (TUZ-MPA) needs awareness among stakeholders, public, and decision makers to protect coastal resources by providing information as management guidance (Bawole et al. 2011). Management actions will be responsive when the diagnostic characteristics of stakeholders can be well recognized. Framework of coastal ecosystem degradation in TUZ-MPA can be done through the assessment of all pressure generating components, which in turn can be formulated in the form of sustainable governance and synergy/integration in policy with many stakeholders. Almost all issues related to coastal resources management are characterized by 2 major domains, those are degradation or decrease in resources and conflict between resource users both inter and intra stakeholders (Norontha 2004). Therefore, this study aimed at identifying and mapping the interest and influence of stakeholders on TUZ-MPA, analyzing form and degree of conflicts, and conflict resolution that can be offered.

\section{Methods}

The study was initiated in August 2010 and carried out until June 2011 in CBNP area which is located in Wondama Bay Regency. Data collected included primary and secondary data. Primary data were collected through observation and direct measurement on the study objects, focus group discussion, and questionnaires. Samples of informant were selected by using purpossive sampling and snowball sampling, considering that selected informants are actors, either individuals or institutions, and they understand the issue. Thirty-five key informants represented individuals and institutions. Key informants were selected hierarchically from village, sub-district, district, and province, representing 
all interest that influence TUZ-MPA. The stakeholder analysis is conducted by following the guidelines of Bryson (2003) and Reed et al. (2009), i.e. by: (1) identifying stakeholders and their interest/influence, (2) grouping and categorizing stakeholders, and (3) investigating the relationships among stakeholders. The result of identification are included in 6 groups, those are central government, regional government (province, regency, district, and village), community, non-government organizations (NGOs), academicians, and private sector (Table 1). Answers from stakeholders were transformed into quantitative data by making criteria of stakeholders' interest and influence. Determination of scoring for the questions referred to measurement of 5 scale ranking (very high, high, medium, less, and low). The stakeholders were asked to give scores to 12 questions on management of TUZ-MPA based on interest and influence scales. Score from each stakeholders were summed up and arranged in a matrix of interest and influence. A matrix-plot analysis was then used to examine the interest and influence of stakeholders on the management activities of TUZ-MPA. Then, the results of interest and influence scales from plot analysis were divided into 2 to make 4 quadrants of stakeholders' interest and influence (Reed et al. 2009; Bryson et al. 2011) (Figure 1).

The position of stakeholders in the 4 quadrans depicts interest and influence of each stakeholder on the sustainability of TUZ-MPA governance, i.e. as: (1) subject (high interest but low influence), (2) key players (high interest and influence), (3) crowd (low interest and influence), and (4) context setters (low interest but high influence). Based on this mapping a qualitative analysis was conducted to examine sources of conflict, form and degree of conflict, and conflict resolution. Stakeholder analysis positioned one stakeholder relative to others in the context of interest and influence through data analysis from available institutions. The further development of this instrument was based on group ranking of the stakeholders, according to how important and strong (influencing) they are to the sustainability of TUZ-MPA management.

Table 1 Stakeholders related to TUZ-MPA

\begin{tabular}{cll}
\hline No & \multicolumn{1}{c}{ Stakeholders } & \multicolumn{1}{c}{ Group } \\
\hline 1 & Management body of Cendrawasih Bay National Park & National government \\
2 & Park rangers & National government \\
3 & Provincial board of planning & Provincial government \\
4 & Regency board of planing & Regency government \\
5 & Provincial office of tourism & Provincial government \\
6 & Regency office of tourism & Regency government \\
7 & Provincial office of marine affairs and fisheries & Provincial government \\
8 & Regency office of marine affairs and fisheries & Regency government \\
9 & District government & Regency government \\
10 & Village government & Regency government \\
11 & Youth leaders & Community \\
12 & Education leaders & Community \\
13 & Religious leaders & Community \\
14 & Indigenous community institutional & Community \\
15 & Enviromental conservation forum & Community \\
16 & Fisher groups & Community \\
17 & Non-government organization & NGO \\
18 & Academicians & Academicians \\
19 & Local fish traders & Private sector \\
\hline
\end{tabular}

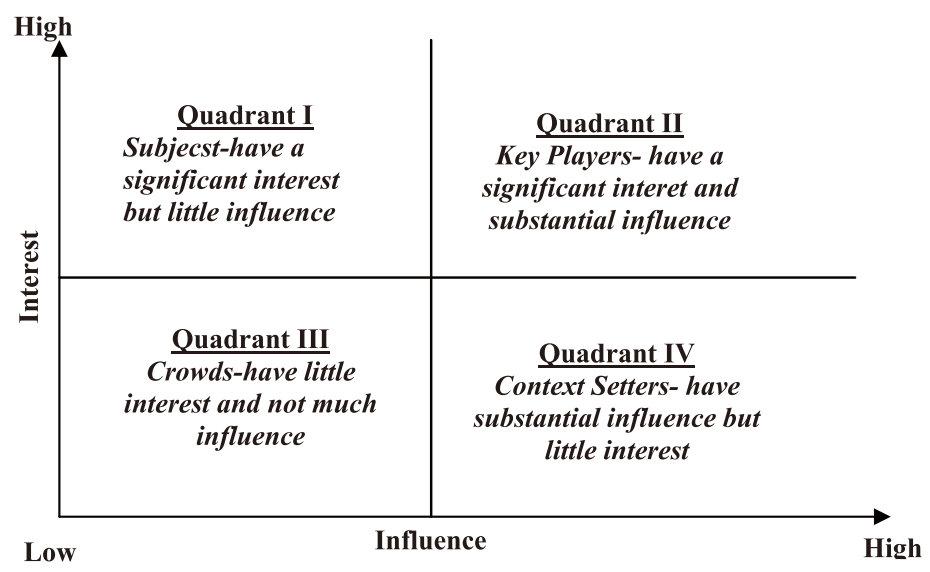

Figure 1 Influence versus interest in grid (quadrant) of stakeholder analysis (Bryson 2003; Reed et al. 2009). 


\section{Results and Discussion}

Mapping and analysis of stakeholders Stakeholders are individuals, groups, organizations, and communities involved in an daffected by decisions made in managing social-ecological systems (Rockloff \& Lockie 2006). Stakeholder analysis a systematic approach to gather information about actors involved in TUZ-MPA management. It groups the actors' positions and identifies their relationships and interactions, especially on operational activities, conflicts, internal, and external processes. Various classification systems of analysis and mapping of stakeholders have been developed in the literature of natural resources. For example, a system of analysis of stakeholders in business management is used by Mitchell et al. (1997) and is adapted by Mikalsen and Jentoft (2001). It is used by Grimble et al. (1995) and Brown et al. (2002). It is adopted also by Evans (2009).

Analysis of stakeholders emphasized the importance of attributes that portraits the extent to which stakeholders are affected by decisions made and affect the level of the stakeholders of the aspects of the decisions. In general, the attributes of interest and influence in the context of decisions relating to management of coastal resources, especially the area of TUZ-MPA. These attributes are used to categorize the importance of the stakeholders in various typologies of roles.

Nineteen stakeholders are mapped to assess their interests and influences in the management of TUZ-MPA (Figure 2). Stakeholders in quadrant I are stakeholders who have high of interests and low of influences (subject). Quadrant I is occupied by 2 stakeholders, namely provincial tourism agency and local traders, and the set who stakeholders have high interests but low influence on the TUZ-MPA. These findings support previous research regarding the determination and the perceptions of stakeholders in the process of zoning of CBNP (Sembiring et al. 2011). Therefore, these stakeholders must be empowered by strengthening their institutions and regulations, technical competence, and representativeness in the management of TUZ-MPA.

In quadrant II (keyplayers) there are 16 stakeholders who are the most critical because they have high interests and high influences. Quadrant II is the area of key stakeholders in the implementation of the fulfillment of criteria and indicators of the sustainability of the management of TUZMPA. Performance of the stakeholders will be high if the key players carry out their functions to their full potentials (Evans 2009). Therefore, in order to improve the sustainability of the management of TUZ-MPA, the strategy of division of roles and functions of institutions in development and community empowerment activities carried out by means of collaboration. Furthermore, quadrant II can be categorized into 3 groups based on their interests and influences on the sustainability of the management, namely:

1 The first group is key stakeholders. It is the most decisive stakeholder group in determining the success of the management of TUZ-MPA (regency office of marine affairs and fisheries (OMAF), management body of CBNP (MBCBNP), park rangers, and regency office of tourism). MBCBNP as the governing body has the

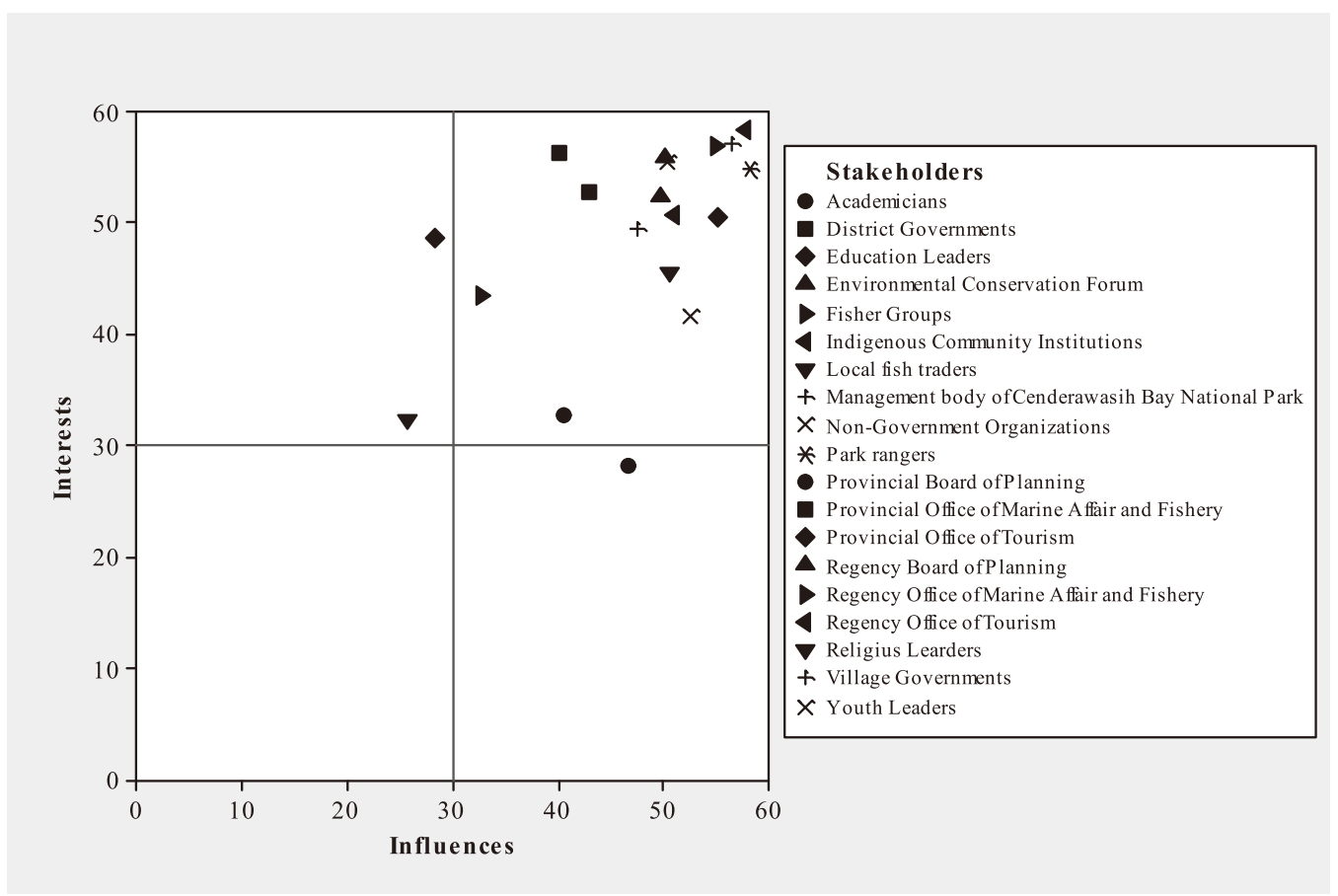

Figure 2 Mapping analysis of the interests and influences of stakeholders. 
authority in the preservation and protection of biodiversity areas including issuing licenses. Regency office of tourism and regency OMAF have equally high influences but the interest of the Regency OMAF is slightly higher than that of the regency office of tourism. regency OMAF has the authority to issue fishery business license (FBL) and fishery catching license (FCL) to the public. This group of stakeholders has direct community economic empowerment programs, so its position is crucial to successful management.

2 The second group of stakeholders is government officials of village and sub-regency provincial office of tourism, community leaders (education, health, youth), enviromental conservation, $\mathrm{NGO}$, and indigenous community institute (ICI). This group can be said as supporters or facilitators in the implementation of activities but the presence of the stakeholders is essential for the effectiveness of the management activities. ICI is an agency representing indigenous communities and facilitates the aspirations of the community. ICI is essential in protecting the rights of indigenous people. It has an important role and a high power in facilitating and in determining development policy. Traditionally, the existing local natural resources are regulated by customary rights and they have very close relationships with social and cultural activities.

3 The third group is a fisher groups which are a target of activities in the field. These stakeholders can become object as well as subject of economic empowerment activities at regency and village levels. Members of this group generally have low education levels $(76.73 \%$ had elementary education), thus requiring assistance in improving their economic activities, especially fish trading activities as the basis of household economic activities. In addition, the fisher group need empowerment to increase the capacity of individuals and groups in conservation activities, especially activities in monitoring and securing the area.

Quadrant III (crowd) is empty because its interest and influence are very low. Quadrant IV is occupied by academicians and its existence can be ignored. However, because the resource use policy is a multi-stakeholder in character and it produces a collaborative decision, then all the stakeholders can be managed to achieve management to objectives. Academicians, generally, have roles in preparing and for mulating recommendations or decisions and bridging opinions in the management of TUZ-MPA (Sembiring et al. 2010). Interesting thing that can be found in the stakeholder analysis above is that the type of matrix of stakeholder interest and influence can change in time, and the effects of the change should be anticipated. Stakeholders in key player position should be considered and managed well because they have high interests and high influence on the sustainability of TUZ-MPA. If the position of a stakeholder is a subject then it needs out reach and empowerment activities. If they are not managed properly, they are likely to oppose the management and then they will form alliances, and in time they will be come key players but they can be the source/cause of conflict as they attempt to demonstrate their presence (Bryson 2003; Bryson et al. 2011).

The results of the research show that almost all stakeholders have high interests and high influences on the sustainability of the management. This is caused by the fact that all identified stakeholders have interests and influences in the TUZ-MPA. This condition is seen from the absence of stakeholders in quadrant III (as crowd). However, the dynamics of stakeholder shifts can also occurand should be anticipated, particularly for stakeholders whose position adjacent to the axis (interest and influence). Stakeholders with a great chance to shift are local fish traders that can move from a position of subject to key player, because their position is only one level to the left of the axis of the degree of influence, or from subject into crowd because its position is slightly above the axis of interest. Therefore, these stakeholders need to be managedso that their roles as subject are firm, and according to Sembiring et al. (2010) it is sufficient just to provide this group information about the sustainable management efforts. Academicians that occupy quadrant IV as context setter is also quite high in influence as the position is at a point below the axis. These stakeholders, at some point, probably will become key players. The fisher groups and the provincial office of tourism can move to the position of subject. Two of these stakeholders need to be considered as having high interest and high influence to the utilization of TUZ-MPA.

Source of conflict The stakeholder mapping analysis as described previously, and also based on interviews with various parties, shows the existence of conflicts of the utilization of TUZ-MPA. There are 2 main types of conflicts, i.e. conflicts among users and conflict among governmental institutions that regulate the governance of the area. Conflicts between government institutions and conflicts between users are often inter-related and coalesce. For example, there is an agreement made between fisher and the holder of customary rights but without recognition of $\mathrm{MBCBNP}$ as area manager. This circumstance often leads to new conflicts, particularly between users and the government. Direct users that participate in resource use activities include fisher, subsistence users, marine transportation, and tourism activities. Indirect users can derive from NGOs who works in the creation of good quality environment.

The conflicts of the utilization of TUZ-MPA are generally still close (latent) ones which are characterized by the existence of tensions and disagreements between users at an early stage. At this time, there has not any open dispute yet, or even the users are often not yet aware of the presence of the gap of understandings. Close conflict is found in the implementation of programs between MBCBNP with NGO, both at administrative level of work (plan of activities) and at community assistance activities. Latent conflicts that occur between NGO and MBCBNP is related to mechanism of action of NGO as one of the management's partners in the management of CBNP. World Wide Found for Nature (WWF) is an NGOs that initiated the formation of CBNP from the beginning, and their existence in the management of this area has been more than 20 years. This NGO provides technical assistance and funding so it is a major donor agency 
in the management of CBNP. The latent conflict is related to taboo (sasi in Indonesia) at Roswar Island (Cape Nyuderpum) in 2009 upon the initiation of the community and facilitated by NGO (Sembiring et al. 2010). While MBCBNP claims that the sasi activity has been performed in the no-taking zone. A clarification from NGO states that the taboo is done based on the will of the community in relation to fundraising efforts for the development church and the location coincides with the core zone.

Open conflicts exist between regency OMAF and fisher (groups or individuals). The conflict is characterized by a dispute which is in the process of finding a solution in form of negotiation. The conflict is related to the fishery business license (FBL) and fishery catching license (FCL), issued by the regency OMAF of Wondama Bay Regency, located in Kampong Roswar and Yende with owners of customary rights. As a result, there is a rejection of the issuance of FBL and FCL in the community customary rights area. At a further stage the community wants a compensation for fishing in the customary area. Open conflict also happens between MBCBNP and OMAF of regency in relation to the authority of the management of natural resources, especially marine resource. MBCBNP as the area authority claims that every activity that is done in TUZ-MPA area must be known and monitored well, while regency OMAF also claims that the management of marine area is the authority and responsibility of Teluk Wondama Government so any activity does not have to be known by MBCBNP. MBCBNP has established a zoning system as a management system implemented within the area. The process of the establishment of the zoning system has taken a very long time for considering the needs and aspirations of local communities and government. Currently, there is a desire of regency OMAF of to review the zoning of coastal and small islands. The regency OMAF indicates that the information used in determining the zoning is not strong, particularly in the aspects of bio-ecology of biological resources. The location of potential fishing is currently designated as core zone of CBNP, and this is the cause of the open conflict between MBCBNP and the regency's OMAF. Another thing that is confirmed by the regency OMAF is that entry permit to conservation areas (or SIMAKSI in Indonesia) issued by MBCBNP should only be applied to tourists and researchers, and not to fishing activities. Fishermen with FBL and FCL issued by regency OMAF do not require a SIMAKSI. The Regency OMAF expresses an objection if the holders of FBL or FCL who are fishing are inspected by MBCBNP sea patrol. Fishing activities which are permitted by the Regency OMAF are considered illegal by the MBCBNP because it is not accompanied by MBCBNP's SIMAKSI (Sembiring et al. 2010).

A condition without conflicts occurs in relationships between regency board of planing, MBCBNP, and regency OMAF. Conflict mapping is a technique to graphically depict the conflict, and connect relevant parties (Figure 3). It is needed to understand the situation well and to look clearly at relationships between various parties. Conflicts can occur at different levels and at different scales of activities in the field. Sembiring et al. (2010) found institutional weakness of
CBNP causing that the conservation area is de facto relatively open access. This created economic opportunities for each party to exploit natural resources available in the area of CBNP. Economically, TUZ-MPA becomes very strategic in ensuring the sustainability of resources in it. Its strategic importance can be seen at least from 2 points, namely economic activities of household which is based on natural resources that bring in cash and also has a high market value. These conditions result in short time preference, i.e. each resource users will take maximum profit in a short time. As a result, the depletion of both quantity and quality of the resource is inevitable if there are no laws that regulate it. For example, when government institution is not yet strong in terms of rules and sanctions related to resource management, then other users will utilize the resources with high economic value without control. Conversely, if community institutions are weak, then other party (e.g. government through investors) will try to use it by way of issuing FBL and FCL for exploiting the resources. This phenomenon often occurs repeatedly in Wondama Regency, especially the utilization of fishery resources in the TUZ-MPA. In fact in many cases, the incidence can be done with only a permission of the owner or the consent of customary rights and/or the village head. The permission is granted for a compensation of $\mathrm{Rp} 500,000$ per month.

Conflict resolution The effectiveness of conflict resolution is highly depending on area managers in understanding the sources or root causes of the conflict. Cicin-Sain and Knecht (1998) stated that a lot of conflict comes from the difference in facts or interests of the resource compared to conflict due to differences in values. Conflict mapping and analysis of stakeholders as described previously show that the conflict stems from the seizure of the use of fishing areas and the species/commodity that is the target of the catch. On the other hand, the institutional capacity of MBCBNP as CBNP's mandate holder is not yet able to manage such a vast region, with a very limited quantity of human resources. Likewise, the regency OMAF is still faced by problems of limited infrastructure and human resources. NGO is also still working on the entire CBNP area which is so large that the community empowerment and outreach become very difficult.

Area utilization, species of captured commodities, and the allocation of space can become sources of conflict that poses a threat to the integrity and sustainability of resources and the environment. This condition indicates that the greatest threat to the integrity and sustainability of conservation areas actually comes from government institutions (central and autonomous regions) in the implementation of activities in the field. The unmanageable sources of conflict result in negative effects on the sustainability of the management of TUZ-MPA. According to a Cicin-Sain and Knecht (1998) there are 3 main elements in the resolution of conflicts related to the management of coastal and marine areas, namely (1) attempts to understand the root causes and the consequences of the conflict through conflict mapping studies, (2) the creation of a transparent process in decision-making, and (3) the ability to adopt and implement measurement indicators to repair damage caused 


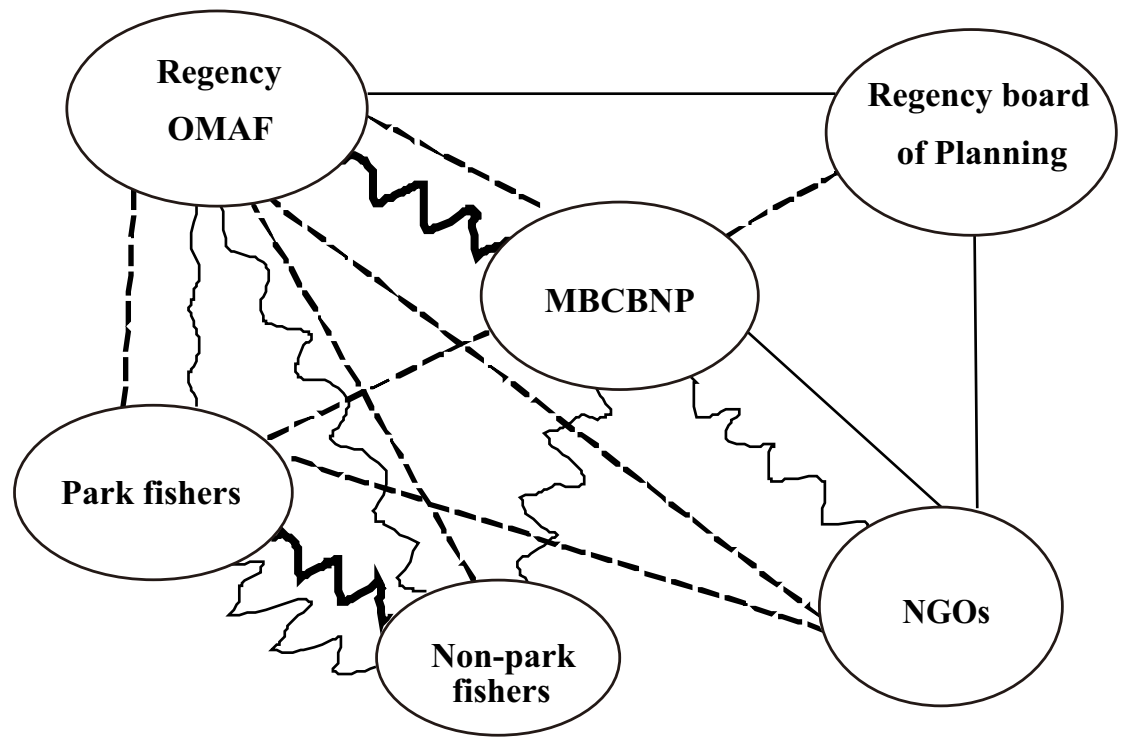

Figure 3 Mapping of conflict and relationships among stakeholders in the TUZ-MPA. Stakeholders (O); open conflict (authority, lisence, and catch target) ( $\sim$ ); close conflict (access to data and information) ( ح几 ); intensive coordination, cooperation, and consultation (— (management body of CBNP); regency OMAF (office of marine affairs and fisheries); NGOs (non-government organization); park fishers (local fishers who fish in the CBNP); non-park fishers (fishers come from outside of the CBNP who fish in the CBNP).

by the utilization of coastal and marine users or other users of the activities outside the coastal and marine areas. Thus, the main challenge for MBCBNP and the regency OMAF as the leading sectors area managers is to understand the root causes of conflicts and to formulate consensus. This is aimed at making other stakeholders are able to create partnerships to support the sustainability of the management of TUZ-MPA. Systematic mapping of conflict and discussion conducted with participants in the handling of the conflict, as well as the ability to identify the position of the stakeholders can be used as a reference for finding solutions to address management issues.

The current conflicts are related to protected biota (fish, sea cucumbers, trochus) but become the targets of the catch. Zoning should be established to ensure the distribution of access or fair profits for the various stakeholders. In this context, the managers (MBCBNP and regency OMAF and assisted by NGO) must often intervene to resolve the conflicts. This is important because: (1) conflicts can threaten public interests which have impacts on economic uncertainty, (2) conflicts that happen in the long run threaten the sustainability of resources and create unrecoverable environmental damages, (3) community participation in the settlement of conflicts represent all related interests, (4) conflicts can be shifted from one type of conflict to the other, so the problem becomes more widespread and often takes a long time to resolve them, and (5) conflicts can inhibit the programs that are planned to be implemented.
The following describes conflict resolution that can be a reference in efforts to realize the better management of TUZMPA:

1 Understand both the types and sources of potential conflict that may arise in the utilization of traditional zone. This step can be done in form of on-site analysis of historical conditions of use as well as in other locations that have similar conditions and have experienced conflict.

2 Identify the conflicting constituents and stakeholders. This stage can be done through a process of discussion and observation for a fact-finding and system analysis of linkage of interest with the background of the chosen position/issues by each party.

3 Identify the needs of concerned constituents and stakeholders. This phase is expected to be able to explain the core of the conflict and the level of the conflict so that problems can be found accurately and clearly.

4 Determine the boundaries of space (delineation) of each interest in accordance with the wishes of the constituents and stakeholders who have conflicting interests. The results of this delineation are areas occupied by more than one use of conflicting interests.

5 Analyzing alternative uses that are accepted by parties with the different interests. This opens the possibilities to find forms of new utilization activities that are better suited to the characters of the stakeholders' interests. The selection of alternatives should be based on physical, social, and economic suitability of the location. 
6 Convey information through public consultation by involving stakeholders especially those of different interests. The consultation process is carried out in stages (district, regency, province), but in levels towards the determination of choices that are agreed by or represent the majority of users.

Assign alternatives of solution of coastal resource use agreed by parties with different interests in form of regulation that is binding to all parties. At community level it can be done in form of a ceremonial program called "spreading the traditional mat" on an agreement that was made which is both socially and culturally binding, and more valued by the community. This process then needs to be followed by more detailed arrangements of the type, location and boundary of spatial utilization which is binding to all parties.

Unlike other national parks in Indonesia, CBNP was formally managed since 1990, but the strategic plan and new zoning was established in 2009. In terms of coastal governance, the management of CBNP was, at the beginning, generally considered by some to have been inadequate. Furthermore, the zoning plan of CBNP was established to regulate the activities of protection, development and enhancement of coastal values. However, the established TUZ-MPA does not yet accommodate every activity such as industrial development, aquaculture, and coastal environment protection actions. On the other hand, at the regency level structures and patterns of space utilization of TUZ-MPA has not been developed and adopted to accommodate all stakeholders associated with the activities on coastal areas. In fact, in the TUZ-MPA there are a lot of users' interests that must be accommodated. Ecosystembased approach is an attempt to maintain ecological benefits including the provision of coastal goods and services that provides benefits (welfare) for humans (Henocque 2003). Spatial management of TUZ-MPA aims to provide a mechanism to achieve consensus among users of all sectors. Ecosystem-based approach accommodates that the coastal/marine environment consists of the elements of nature and human that are interconnected in socialecological systems in space and time scales. To involve communities in decision-making process and to allocate marine space (3-dimensional) is important for specific use in achieving ecological, economic, and social objectives. Thus, the participation of stakeholders and their involvement is an integral part of the success of ecosystembased approach. This process has been accepted around the world to achieve a successful integrated coastal and marine management (Tallis et al. 2010).

\section{Conclusion}

Understanding both the types and sources of potential conflict and conflict resolution can be used as a reference in preparing the TUZ-MPA management scenarios. Conflicts can be resolved by mutual consent based on local culture that is socially and culturally binding and more valued by communities. This process then needs to be followed by more detailed arrangements of species, location, and spatial extent. Interest linkage system with the background of the selected position/issue of management (fishing location and target species) among the stakeholders becomes a key factor in solving management problems.

\section{Recommendation}

The practices of zoning in TUZ-MPA should be integrated with local activities in various regions of Wondama Bay Regency. This is done to achieve the goal of sustainable development, incorporating measures of economic development with environmental protection activities. Ecosystem-based management is an option of ecosystem management process based on human activities. This approach on a regional scale is intended to maintain the sustainability and integrity of ecosystem processes. Ecosystem-based management is needed in collaborative activities with primary focus on the ecosystem as a whole, either on a local scale, or biophysical and culture, which is integrated with various interests of stakeholders.

\section{References}

Bawole R, Yulianda F, Bengen DG, Fahrudin A. 2011. Keberlanjutan penatakelolaan zona pemanfaatan tradisional dalam kawasan konservasi laut Taman Nasional Teluk Cenderawasih Papua Barat. Jurnal Manajemen Hutan Tropika 17(2): 71-78.

Brown K, Tompkins E, Adger WN. 2001. Trade-off Analysis for Participatory Coastal Zone Decision-Making. Norwich: Overseas Development Group University of East Anglia.

Bryson JM. 2003. What to Do when Stakeholders Matter; a Guide to Stakeholder Identification and Analysis Techniques. Washington DC: The Georgetown University, Public Policy Institute.

Bryson JM, Patton MQ, Bowman RA. 2011. Working with evaluation stakeholders: a rationale, step-wise approach. Evaluation and Program Planning 34:1-12. http://dx.doi.org/10.1016/j.evalprogplan.2010.07. $\underline{001}$

Evans LS. 2009. Understanding divergent perspectives in marine governance in Kenya. Marine Policy 33:784793. http://dx.doi.org/10.1016/j.marpol. $\underline{2009.02 .013}$

Grimble R, Chan MK, Aglionby J, Quan J. 1995. Trees and Trade-offs: a Stakeholder Approach to Natural Resource Management. IIED Sustainable Agriculture Gatekeeper Series No. SA52. London: International Institute for Environment and Development.

Henocque Y. 2003. Development of process indicators for coastal management assessment in France. Ocean and Coastal Management 46:363-379. http://dx.doi.org/10.1016/S0964-5691(03)00013- 
$\underline{9}$

Mikalsen KH, Jentoft S. 2001. From user-groups to stakeholders? The public interest in fisheries management. Marine Policy 25:281-292. http://dx.doi.org/10.1016/S0308-597X(01)00015X

Mitchell RK, Agle BR, Wood DJ. 1997. Toward a theory of stakeholder identification and salience: defining the principles of who and what really counts. Academy of Management Review 22:853-86.

Norontha L. 2004. Coastal management policy: observations from an Indian case. Ocean and Coastal Management 47:63-77. http://dx.doi.org/10.1016/j. ocecoaman.2004.03.004

Reed MS et al. 2009. Who's in and why? A typology of stakeholder analysis methods for natural resource management. Journal of Environmental Management 90:1933-1949. http://dx.doi.org/10.1016 /j.jenvman.2009.01.001

Rockloff SF, Lockie S. 2006. Democratisation of coastal zone decision-making for indigenous Australians: insights from stakeholder analysis. Coastal Management $34: 251-266$. http://dx.doi.org/10.1080/08920750600686653

Sembiring S, Basuni S, Soekmadi R. 2010. Resolusi konflik pengelolaan Taman Nasional Teluk Cenderawasih di Regency Teluk Wondama. Jurnal Manajemen Hutan Tropika 16(2): 84-91.

Tallis $\mathrm{H}$ et al. 2010. The many faces of ecosystem-based management: Making the process work today in real places. Marine Policy 34: 340-348. http://dx.doi.org/10.1016/j.marpol.2009.08.003 